\title{
GAMBARAN TINGKAT PENGETAHUAN TENTANG HIPERTENSI SEBAGAI FAKTOR RESIKO STROKE DAN KEPATUHAN MENGKONSUMSI OBAT ANTI HIPERTENSI PADA PENDERITA HIPERTENSI DI RSUP PROF. DR.R.D. KANDOU MANADO
}

\author{
${ }^{1}$ Samuel Rimporok \\ ${ }^{2}$ Karema Winifred \\ ${ }^{2}$ Mieke A.H.N Kembuan \\ ${ }^{1}$ Kandidat Skripsi Fakultas Kedokteran Universitas Sam Ratulangi Manado \\ ${ }^{2}$ Bagian Neurologi BLU RSUP Prof. dr. R.D. Kandou Manado \\ Email : samuelrimporok09068@yahoo.com
}

\begin{abstract}
ABSTRAK
Latar belakang: Stroke adalah suatu penyakit defisit neurologis akut yang disebabkan oleh gangguan pembuluh darah otak yang terjadi secara mendadak dan menimbulkan gejala dan tanda yang sesuai dengan daerah otak yang terganggu. Hipertensi yang tidak diobati adalah penyebab utama stroke.Banyak penderita hipertensi yang tidak sadar dengan karakter penyakit sehingga masyarakat sering mengacuhkan terapi kontrol obat pada hipertensi. Penelitian ini bertujuan untuk mengetahui pengetahuan tentang hipertensi sebagai faktor resiko stroke dan kepatuhan dalam pengobatan pasien hipertensi.Metode: Penelitian ini merupakan penelitian yang bersifat deskriptif yang dilaksanakan dengan metode survei, dimana pengumpulan/pengambilan data diambil pada pasien rawat jalan hipertensi di bagian poliklinik ginjal dan hipertensi interna di RSUP Prof.DR.R.D Kandou Manado.Hasil: Jumlah sampel yang memenuhi kriteria untuk penelitian berjumlah 73 sampel di Bagian poli Interna RSU Prof. R. D. Kandou Manado bulan November 2012, umur dari responden yang terbanyak yaitu 46-65 tahun sebanyak 65 responden (89\%) dan pendidikan terakhir dari responden yang terbanyak adalah pendidikan SLTA sebanyak 30 responden (41.1\%), kebanyakan responden masih bekerja sebanyak 48 responden (65.8\%).Kesimpulan: Berdasarkan dari hasil yang didapatkan, kategori tingkat pengetahuan responden tentang hipertensi sebagai faktor resiko stroke kebanyakan Cukup yaitu 34 responden (46.6\%) kategori untuk kepatuhan mengkonsumsi obat anti hipertensi kebanyakan Baik yaitu sebanyak 39 responden (53.4\%)
\end{abstract}

Kata kunci :Stroke, Hipertensi,Pengetahuan,Kepatuhan.

\begin{abstract}
Background:Stroke is a disease of acute neurological deficits caused by brain blood vessel disorders that occur suddenly and cause symptoms and signs corresponding to the affected brain regions. Untreated hypertension is a major cause of stroke. Many patients with hypertension are not aware of the character of the disease so that people often ignore drug therapy in hypertension control. This study aimed to determine the knowledge of hypertension as a risk factor for stroke and compliance in the treatment of hypertensive patients.Methods: This research is a descriptive study conducted by survey, where collection / retrieval of data taken at the outpatient clinic of hypertension on the kidney and hypertension in the department of internal Prof.DR.RD Kandou Manado.Results: The number of samples that meet the criteria for the study amounted to 73 samples in Part poly Interna RSU Prof. R. D. Kandou Manado in November 2012, the age of most respondents is 46-65 years by 65 respondents (89\%) and education level of most respondents are high school education by 30 respondents (41.1\%), most respondents still working as many as 48 respondents (65.8 \%).Conclusion: Based on the results obtained, the respondents knowledge level category of hypertension as a risk factor for stroke mostly just the 34 respondents (46.6\%) categories for compliance with anti-hypertensive drugs are mostly good total of 39 respondents (53.4\%)
\end{abstract}

Keywords: Stroke, Hypertension, Knowledge, Compliance 


\section{Latar Belakang}

Stroke merupakan salah satu masalah kesehatan yang serius karena ditandai dengan tingginya morbiditas dan mortalitas.Stroke ditemukan pada semua golongan usia, namun sebagian besar akan dijumpai pada usia diatas 55 tahun. Ditemukan kesan bahwa insiden stroke meningkat secara eksponensial dengan bertambahnya usia, di mana akan terjadi peningkatan 100 kali lipat pada mereka yang berusia 80-90 tahun.

Hipertensi atau tekanan darah tinggi adalah keadaan peningkatan tekanan darah yang akan berlanjut pada suatu organ target seperti stroke ${ }^{1}$

Insiden stroke secara nasional diperkirakan adalah 750.000 per tahun, dengan 200.000 merupakan stroke rekuren. ${ }^{2}$

Hasil Riset Kesehatan Dasar (Riskesdas)

2007 ditemukan prevalensi hipertensi di Indonesia sebesar $31,7 \%$, dimana hanya $7,2 \%$ penduduk yang sudah mengetahui memiliki hipertensi dan hanya $0,4 \%$ kasus yang minum obat hipertensi. Banyak penderita hipertensi yang tidak sadar dengan karakter penyakit ini yang timbul tenggelam. Ketika penderita dinyatakan tekanan darahnya sudah normal, mereka menganggap kalau kesembuhan mereka permanen, padahal hipertensi bisa terjadi kembali. ${ }^{3}$ Penggunaan obat-obat antihipertensi sangat dianjurkan bagi penderita hipertensi. Namun sering terdapat pendapat keliru di masyarakat bahwa mengonsumsi obat antihipertensi akan menyebabkan ketergantungan.Hal ini menyebabkan beberapa penderita hipertensi enggan, dan baru mulai mengkonsumsi obat antihipertensi saat sudah terjadi kerusakan organ.Sehingga tidaklah mengherankan bila pada lebih dari $20 \%$ penderita stroke, baru mengetahui bahwa dirinya menderita hipertensi saat sudah terkena stroke. ${ }^{4}$

\section{Rumusan Masalah}

Berdasarkan data dalam latar belakang maka permasalahan yang dapat dirumuskan adalah untuk mengetahui tingkat pengetahuan tentang hipertensi sebagai faktor resiko stroke dan kepatuhan meminum obat hipertensi pada penderita hipertensi.

\section{Tujuan Penelitian}

\section{Tujuan Umum}

Untuk mengetahui pengetahuantentang hipertensi sebagai faktor resiko stroke dan kepatuhan dalam pengobatan pasien hipertensi.

\section{Tujuan Khusus}

1. Untuk mendeskripsikan tingkat pengetahuan tentang hipertensi sebagai faktor resiko stroke.

2. Untuk mendeskripsikan kepatuhan dalam pengobatan penderita hipertensi.

\section{Manfaat Penelitian}

Dapat memberikan sumbangan dalam perkembangan ilmu pengetahuan yang berhubungan dengan hipertensi sebagai faktor resiko stroke dan pentingnya pengobatan hipertensi , dapat memberikan penyuluhan/ informasi kepada pasien hipertensi tentang pentingnya pengobatan hipertensi dan dapat digunakan sebagai bahan penelitian selanjutnya.

\section{METODE PENELITIAN}

Penelitian ini merupakan penelitian yang bersifat deskriptif yang dilaksanakan dengan metode survei.

Penelitian dilaksanakan selama satu bulan yaitu pada bulan November 2012 bertempat di RSUP Prof.DR.R.D Kandou Manado. Dengan populasinya adalah pasien hipertensi di RSUP Prof.DR.R.D Kandou Manado. Pasien rawat jalan hipertensi di bagian poliklinik ginjal dan hipertensi interna selama waktu penelitian berjalan. Teknik pengambilan sampel dengan teknik simple random sampling, dimana jumlah subjek dalam populasi yang tidak diketahui akan dipilih dan dihitung terlebih dahulu dengan menggunakan Formula Snedecor dan Cochran. Seluruh sampel berjumlah 73 orang.

Pada penelitian ini menggunakan data primer yaitu kuesioner. Pengukuran kuesioner menggunakan skala Guttman dimana jawaban Positif adalah bernilai 1 dan jawaban Negatif adalah bernilai 0.Data yang diperoleh akan di kumpulkan dan di olah, baik secara manual maupun dengan menggunakan komputer kemudian akan di tampilkan atau disajikan dalam bentuk tabel distribusi frekuensi serta menggunakan program SPSS versi 17 untuk pengolahan data. 


\section{HASIL PENELITIAN}

\section{Karakteristik Responden}

Berdasarkan hasil penelitian, diperoleh bahwa umur 40-59 tahun menjadi umur terbanyak dengan 41 orang $(56.2 \%)$, dan yang umur 20-39 tahun menjadi umur yang paling sedikit/terendah jumlahnya dengan 2 orang (2.7\%). Dari hasil penelitian ini didapatkan bahwa pendidikan terakhir dari responden yang terbanyak adalah pendidikan SLTA sebanyak 30 orang $(41.1 \%)$, SLTP sebanyak 16 orang $(21.9 \%)$, kemudian akademi/ sarjana berjumlah sebanyak 15 orang (20.5\%), SD sebanyak 10 orang $(13.7 \%)$ dan yang berpendidikan paling terendah adalah Tidak sekolah berjumlah 2 orang atau tidak ada sama sekali $(2.7 \%)$. Pada hasil penelitian diperoleh, di mana kebanyakan responden kebanyakan responden telah bekerja sebanyak 48 orang $(65.8 \%)$ dan responden yang tidak bekerja sebanyak 25 orang (34.2\%)

\section{Pengetahuan responden tentang hipertensi sebagai faktor resiko stroke}

Berdasarkan hasil penelitian didapatkan bahwa sebanyak 58 responden $(79.5 \%)$ telah mengetahui penyakit hipertensi merupakan tekanan darah yang tinggi.Sebanyak 57 responden $(78.1 \%)$ telah mengetahui bahwa penderita hipertensi harus memeriksakan tekanan darah ke pelayanan kesehatan terdekat secara rutin.
Sebanyak 47 responden (64.4\%) telah mengetahui bahwa membatasi makanan berlemak merupakan salah satu usaha untuk mencegah tekanan darah tinggi. Sebanyak 47 responden $(64.4 \%)$ telah mengetahui bahwa Mengkonsumsi garam berlebihan akan menyebabkan tekanan darah meningkat.

Sebanyak 38 responden $(52.1 \%)$ tidak mengetahui bahwa tekanan darah tinggi berhubungan dengan stroke. Dan sebanyak 38 responden $(52.1 \%)$ telah mengetahui merokok dan minuman alkohol merupakan penyebab timbulnya kekambuhan penyakit tekanan darah tinggi. Sebanyak 58 responden $(79.5 \%)$ telah mengetahui bhwa menjauhkan diri dari stress salah satu cara untuk mencegah tekanan darah tinggi.

Pengetahuan tentang tekanan darah tinggi yang tidak terkontrol sangat erat kaitannya dengan terjadinya stroke telah diketahui sebanyak 42 responden $(57.5 \%)$. Dan sebanyak 55 reponden $(75.3 \%)$ telah mengetahui bahwa meminum obat anti hipertensi secara teratur dan seumur hidup serta mengontrol pola makanan adalah usaha mencegah terjadinya stroke.Serta 51 responden $(69.9 \%)$ telah mengetahui bahwa menjaga tekanan darah dalam batas normal dapat mengurangi resiko terjadinya stroke.

Berdasarkan hasil data diatas maka dapat dikelompokkan menjadi 3 kategori tingkat pengetahuan, di mana masing-masing kategori tersebut dapat dilihat pada tabel1.

Tabel 1. Distribusi Responden berdasarkan Kategori Pengetahuan responden tentang hipertensi sebagai faktor resiko strokedi RSU Prof. R. D. Kandou Malalayang, Manado Tahun 2012.

\begin{tabular}{ccc}
\hline Pengetahuan & $\mathrm{n}$ & $\%$ \\
\hline Baik & 33 & 45.2 \\
Cukup & 34 & 46.6 \\
Kurang & 6 & 8.2 \\
\hline Total & 73 & 100
\end{tabular}

\section{Kepatuhan Pasien Mengkonsumsi Obat Antihipertensi}

Berdasarkan hasil penelitian maka dapat bahwa kepatuhan mengkonsumsi obat sebanyak 69 responden $(94.5 \%)$ sudah mengkonsumsi obat anti hipertensi. Sebanyak 69 responden $(94.5 \%)$ telah mengetahui bahwa penting mengkonsumsi obat anti hipertensi.

Sebanyak 44 responden $(60.3 \%)$ sudah mengkonsumsi obat anti hipertensi setiap hari.Dan sebanyak $52 \quad(71.2 \%)$ responden menjawab tidak mengkonsumsi obat anti hipertensi hanya ketika tekanan darah sangat tinggi dan merasa pusing saja.Serta 51 responden (69.9\%) menjawab obat anti hipertensi harus diminum rutin setiap hari.

Berdasarkan hasil data diatas maka dapat dikelompokkan menjadi 3 kategori kepatuhan , di mana masing-masing kategori tersebut dapat dilihat pada tabel2 ini. 
Tabel 2. Distribusi Responden berdasarkan Kategori Kepatuhan mengkonsumsi Obat Antihipertensi diRSU Prof. R. D. Kandou Malalayang, Manado Tahun 2012.

\begin{tabular}{ccc}
\hline Pemberian MP-ASI & N & $\%$ \\
\hline Baik & 39 & 53.4 \\
Cukup & 22 & 30.1 \\
Kurang & 12 & 16.4 \\
\hline Total & 73 & 100 \\
\hline
\end{tabular}

\section{PEMBAHASAN}

\section{Pengetahuan responden tentang hipertensi sebagai faktor resiko stroke}

Berdasarkan hasil penelitian diatas tentang pengetahuan tentang hipertensi sebagai faktor resiko stroke dapat dilihat pada tabel 1, dimana lebih dari setengah keseluruhan responden $(79.5 \%)$ telah mengetahui penyakit hipertensi merupakan tekanan darah yang tinggi. Seperti yang telah diuraikan oleh Bustan bahwa Hipertensi atau tekanan darah tinggi adalah keadaan peningkatan tekanan darah yang akan berlanjut pada suatu organ target,namun masih ada yang belum mengerti tentang pengertian hipertensi. ${ }^{1}$

Lebih dari setengah keseluruhan responden responden (78.1\%) telah mengetahui bahwa penderita hipertensi harus memeriksakan tekanan darah ke pelayanan kesehatan terdekat secara rutin. Menurut penjelasan Bustan, Hipertensi akan berlanjut pada suatu organ target seperti stroke (pada otak),penyakit jantung koroner (pada pembuluh darah jantung) dan hipertrofi ventrikal kanan atau kiri(pada otot jantung). ${ }^{1}$ Jadi pada penderita Hipertensi sangatlah penting untuk memeriksakan tekanan darah secara rutin.

Lebih dari setengah keseluruhan responden $(64.4 \%)$ sudah mengetahui bahwa membatasi makanan berlemak merupakan salah satu usaha untuk mencegah tekanan darah tinggi. Lebih dari setengah keseluruhan responden $(64.4 \%)$ telah mengetahui bahwa Mengkonsumsi garam berlebihan akan menyebabkan tekanan darah meningkat. Padahal menurut penelitian sebelumnya, Faktor makanan juga merupakan penentu tingginya tekanan darah meliputi intake lemak jenuh yang tinggi yang menyebabkan kelebihan lemak tubuh atau obesitas, intakegaram yang tinggi, intake kalium yang rendah. $^{5}$
Lebih dari setengah keseluruhan responden $(52.1 \%)$ tidak mengetahui bahwa tekanan darah tinggi berhubungan dengan stroke, dan hanya sebanyak 35 responden (47.9\%) yang sudah menjawab benar bahwa tekanan darah tinggi berhubungan dengan stroke.Hipertensi merupakan faktor risiko stroke yang paling konsisten dari berbagai penelitian terdahulu, Hipertensi merupakan faktor risiko stroke yang paling penting, meningkatkan risiko stroke sampai 2-4 kali lipat. ${ }^{6}$

Lebih dari setengah keseluruhan responden (52.1\%) sudah mengetahui merokok dan minuman alkohol merupakan penyebab timbulnya kekambuhan penyakit tekanan darah tinggi dan sebanyak (47.9\%) yang belum mengetahui bahwa merokok dan minuman alkohol merupakan penyebab timbulnya kekambuhan penyakit tekanan darah tinggi. Lebih dari setengah keseluruhan responden $(79.5 \%)$ telah mengetahui bahwa menjauhkan diri dari stres salah satu cara untuk mencegah tekanan darah tinggi. dan sebanyak 15 responden $(20.5 \%)$ yang belum tahu. Masih ada responden yang tidak mengetahui bahwa pola kebiasaan hidup yang buruk merupakan penyebab timbulnya kekambuhan penyakit tekanan darah tinggi, padahal pola kebiasaan hidup yang buruk seperti mudah stress dan merokok menyebabkan peningkatan denyut jantung, tekanan darah, sehingga timbul Hipertensi. ${ }^{5}$

Pengetahuan tentang Tekanan darah tinggi yang tidak terkontrol sangat erat kaitannya dengan terjadinya stroke telah diketahui sebanyak 42 responden $(57.5 \%)$ dan sebanyak 31 responden $(42.5 \%)$ yang tidak mengetahuinya. Peningkatan tekanan sistolik maupun diastolik berkaitan dengan risiko yang lebih tinggi. Untuk setiap kenaikan tekanan diastolik sebesar 7,5 $\mathrm{mmHg}$ maka risiko stroke meningkat 2 kali lipat. $^{6}$ 
Lebih dari setengah keseluruhan responden $(75.3 \%)$ telah mengetahui bahwa meminum obat anti hipertensi secara teratur dan seumur hidup serta mengontrol pola makanan adalah usaha mencegah terjadinya stroke. Serta Lebih dari setengah keseluruhan responden $(69.9 \%)$ telah mengetahui bahwa menjaga tekanan darah dalam batas normal dapat mengurangi resiko terjadinya stroke. Mengontrol tekanan darah berarti juga mencegah timbulnya stroke, Metode yang paling baik dan teraman untuk mengendalikan tekanan darah adalah dengan melakukan perubahan-perubahan gaya hidup. Namun jika tidak membawa perubahan nilai tekanan darah yang diinginkan ,maka perlu diberikan obat-obatan. $^{7}$

\section{Kepatuhan Antihipertensi}

Mengkonsumsi Obat

Berdasarkan hasil penelitian diatas tentang pengetahuan Kepatuhan mengkonsumsi obat anti hipertensi dapat dilihat pada tabel 4.6, hampir seluruh responden yakni sebanyak 69 responden $(94.5 \%)$ telah mengkonsumsi obat anti hipertensi dan hanya 4 responden $(5.5 \%)$ saja yang tidak mengkonsumsi obat. Sama halnya dengan pertanyaan awal, sebanyak 69 responden $(94.5 \%)$ menjawab bahwa penting mengkonsumsi obat anti hipertensi.

Sebagian besar responden sudah sadar bahwa penderita hipertensi harus mengkonsumsi obat dan menyadari obat anti hipertensi itu sangat penting untuk dikonsumsi, hal ini sejalan dengan pernyataan Gardner bahwa jika dengan perubahan gaya hidup tidak membawa perubahan nilai tekanan darah yang diinginkan ,maka perlu diberikan obat-obatan. Obat-obatan juga dianjurkan jika pasien membutuhkan penurunan darah secara drastis dan cepat yang tidak dapat dilakukan hanya dengan perubahan gaya hidup saja. Penggunaan obat juga di anjurkan bila penderita hipertensi yang membutuhkan pengobatan mengalami kondisi medis yang menyertainya. ${ }^{7}$

Sebanyak 44 responden $(60.3 \%)$ telah mengkonsumsi obat anti hipertensi setiap hari dan sebanyak 29 (39.7\%) yang belum mengkonsumsi obat setiap hari.Pengobatan atau penatalaksanaan hipertensi membutuhkan waktu lama, seumur hidup dan harus terus menerus. Jika modifikasi gaya hidup tidak menurunkan tekanan darah ke tingkat yang diinginkan, maka harus diberikan obat secara rutin setiap hari.

Sebanyak $52(71.2 \%)$ responden tidak mengkonsumsi obat anti hipertensi hanya ketika tekanan darah sangat tinggi dan merasa pusing saja.Sebanyak 51 responden (69.9\%) sudah menyadari obat anti hipertensi harus diminum rutin setiap hari.

Masih banyak penderita hipertensi yang tidak sadar dengan karakter penyakit ini yang timbul tenggelam.Ketika penderita dinyatakan tekanan darahnya sudah normal, mereka menganggap kalau kesembuhan mereka permanen, padahal hipertensi bisa terjadi kembali. Masyarakat sering mengacuhkan terapi kontrol obat pada hipertensi. ${ }^{3}$

\section{PENUTUP}

\section{Kesimpulan}

Berdasarkan penelitian mengenai gambaran tingkat pengetahuan tentang hipertensi sebagai faktor resiko stroke dan kepatuhan mengkonsumsi obat antihipertensi pada penderita hipertensi didapatkan bahwa jumlah sampel yang memenuhi kriteria untuk penelitian berjumlah 73 sampel di Bagian poli Interna RSU Prof. R. D. Kandou Manado bulan November 2012, diketahui bahwa hanya $45.2 \%$ atau hampir setengah dari responden yang telah mengetahui bahwa hipertensi sebagai faktor resiko stroke, dan lebih dari setengah responden (53.4\%) yang telah patuh mengkonsumsi obat antihipertensi.

\section{Saran}

1. Masih perlu dilakukan sosialisasi mengenai hipertensi sebagai faktor resiko stroke.

2. Perlunya dilakukan sosialisasi mengenai pentingnya mengkonsumsi obat antihipertensi.

3. Perlu dilakukan penelitian lanjutan dengan sampel lebih besar dan bukan bertempat di rumah sakit.

\section{Ucapan Terima Kasih}

Disampaikan sebesar - besarnya kepada dr. J.Maja P.S Sp.S dan dr. Melke Tumboimbela Sp.S yang telah banyak memberikan saran, kritikan dan masukan kepada peneliti dan kepada seluruh staf bagian Neurologi yang telah 
banyakmembantu dalam penelitian hingga terselesaikannya ini.

\section{DAFTAR PUSTAKA}

1. Bustan, M.N. Stroke. Epidemiologi Penyakit Tidak Menular. Edisi kedua. Jakarta : Rineka Cipta; 2007.

2. PriceSA, Wilson LM. Patofisiologi : Konsep Klinis Proses-Proses Penyakit. Edisi 6. Jakarta : EGC; 2005. p. hal : $1106-22$.

3. Marliani L, Tantan S. 100 Questions \&Answers : Hipertensi. Edisi 2. Jakarta : PT Elex Media Komputindo; 2007. p. hal : 1-2

4. Taruna Y. Hipertensi dan stroke. [online]. Diunduh dari : http://www.medikaholistik.com/medi ka.html?xmodule=document detail\& $\underline{x i d=227 \& t s=1350365476 \& q s=\text { health }}$

5. Rasmaliah, Siregar FA, Jemadi. Gambaran Epidemiologi Penyakit Hipertensi Di Wilayah Kerja Puskesmas Pekan Labuhan Kecamatan Medan Labuhan Kota Medan Provinsi Sumatera Utara [hasil penelitian]. Medan: USU.

6. Bethesda Stroke Center. Hipertensi dan Stroke. Available at http://www.strokebethesda.com . Diaskes 27 okteober 2012.

7. Gardner FS. Hipertensi .Smart treatment for high blood pressure. Jakarta : prestasi Pustaka Raya;2007. p. hal : 125-126 